\title{
LA MEMORIA SEFARDÍ: EL MOBILIARIO LITÚRGICO Y DOMÉSTICO EN LAS HAGADOT MEDIEVALES DE ORIGEN HISPANO
}

\author{
SEPHARDIC MEMORY: LITURGICAL AND DOMESTIC FURNITURE IN THE MEDIE- \\ VAL HAGADOT OF HISPANIC ORIGIN
}

Miguel Ángel Espinosa Villegas*
Departamento de Historia del Arte. Universidad de Granada**

\section{Resumen}

El desconocimiento sobre las piezas de mobiliario de los judíos españoles es prácticamente total, puesto que la arqueología no nos ofrece una base sólida. Quienes salieron se adaptaron rápidamente a los usos y costumbres de los países de acogida y si bien en la lengua judeoespañola persistió la memoria de dichos objetos, en la práctica y en la vida diaria acabaría por perderse la certeza de su imagen y de su uso. La abundante documentación sobre los bienes de los judíos conversos, apoyada en la representación plástica medieval, permitiría una conveniente reconstrucción de los diferentes tipos de muebles y enseres que componían la decoración de la casa judía y de la sinagoga. Las hagadot ofrecen una idea bastante próxima a la realidad rica y variada de este mobiliario.

Palabras clave: Hagadá, Manuscrito iluminado, Mueble medieval, Arte hispanojudío, Sefarad

\footnotetext{
Abstract

The ignorance about the pieces of furniture of the Spanish Jews is practically total since archeology does not offer us a solid base. Those who left quickly adapted to the uses and customs of the host countries and although the memory of these objects persisted in the Judeo-Spanish language, in practice, and in daily life, the certainty of their image and use would eventually be lost. The abundant documentation on the assets of the converted Jews, supported by medieval plastic representation, would allow a convenient reconstruction of the different types of furniture and belongings that made up the decoration of the Jewish house and the synagogue. The Haggadot offer an idea quite close to the rich and varied reality of these pieces of furniture.

Keywords: Haggadah, Illuminated manuscript, Medieval Furniture, Hispano-Jewish Art, Sepharad

*E-mail: espinosa@ugr.es

**Este trabajo se enmarca en los proyectos «Rimon-Sefarad», (Ref. B-HUM-227-UGR18, financiado por FEDER/Junta de Andalucía-Consejería de Economía y Conocimiento, IP: Miguel A. Espinosa Villegas) y «Vestir la casa: espacios, objetos y emociones en los siglos XV y XVI» (VESCASEM), (Ref. PGC2018-093835-B-100, financiado por FEDER/Ministerio de Ciencia e Innovación-Agencia Estatal de Investigación. IP: María Elena Díez Jorge).
} 


\section{Introducción. Las hagadot de Pascua y su relación con el mueble}

Las referencias al mobiliario en la Biblia y sus comentarios no son habituales, de hecho no parece que se repare mucho en él en las descripciones de interiores. Probablemente esto sea debido al enorme sentido práctico del concepto doméstico hebreo. En los comentarios misnaicos su aparición va casi siempre ligada a la posibilidad de mantener o perder su pureza. Tal es el caso de muebles como la caja que puede servir de asiento, la cama que se utiliza para lecho o la tarima que se coloca delante de ella y delante de los escribas ${ }^{1}$. Las noticias contenidas en la Misná insinúan formas y diseños, aunque no se detienen en descripciones. En el tratado titulado Kelim (Utensilios) se nos habla de armarios de madera con puerta metálica ${ }^{2}$, camas compuestas por base, barras y cubiertas cuyos armazones se componen de pequeñas columnillas ${ }^{3}$, mesas recubiertas de mármol, bancos y sillas de diferentes tipos en función de su uso, como las sillas nupciales acolchadas, sillas cubiertas con piel, sillas de artesa, sediles de picapedreros, bancos de balneario ${ }^{4}$.

Las imágenes de las Biblias hebreas medievales tampoco son demasiado prolijas en el tratamiento del mobiliario, con la excepción de las piezas mayores y menores usadas en el Templo y que aparecen descritas en I Re 7, 40-51 y II Cr 4. La mayor parte de los objetos enumerados son realmente de naturaleza más decorativa que funcional y forman parte de una tradición iconográfica que se puede rastrear en los mosaicos de pavimento bizantinos de las sinagogas de la Galilea y Golán o en los pergaminos miniados de las primeras biblias orientales de origen egipcio, siro-palestino o yemenita datadas entre los siglos $\mathrm{X}$ al $\mathrm{XV}^{5}$. En los mosaicos de Bet Alpha o Hammat Tiberias (Fig. 1) se configura ya el arquetipo de lo que habrá de ser el armario santo o aron ha-qodesh de una sinagoga hasta la actualidad, con las mínimas y lógicas variantes estilísticas pero con una estructura simbólica prácticamente inalterable y tomada en préstamo de las culturas inmediatas.

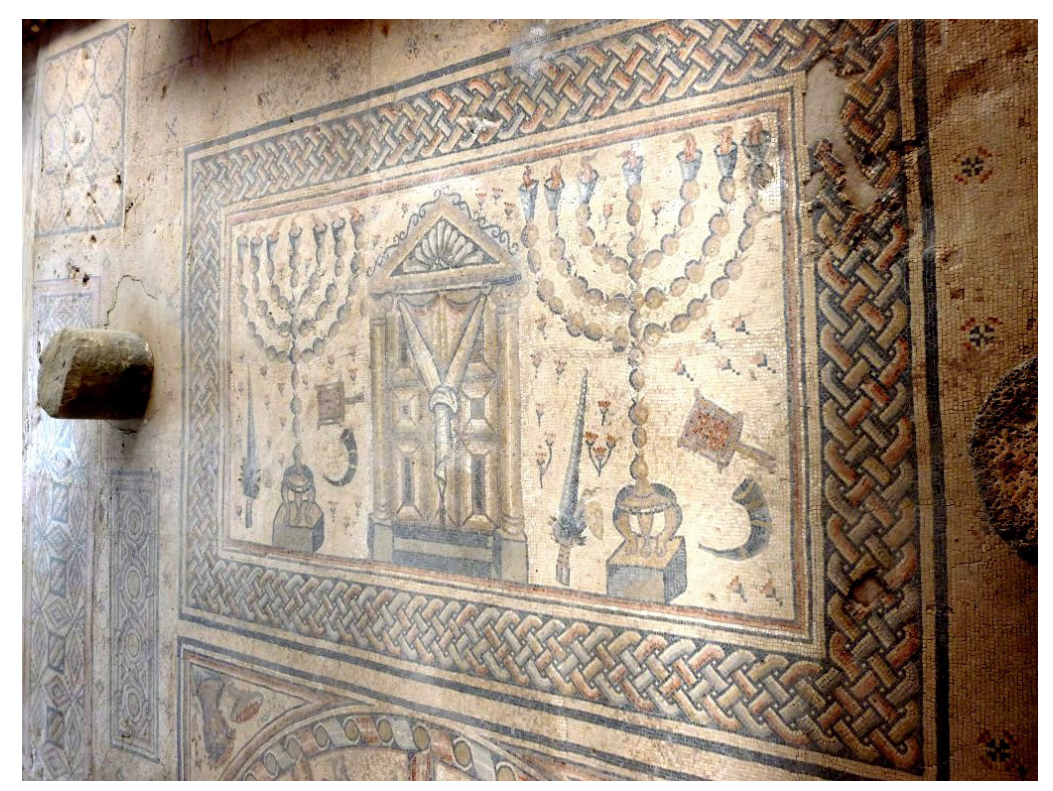

Fig. 1. Aron ha Qodesh. Mosaico de pavimento. Hammat Tiberias, Israel. 365 d. C. https://upload. wikimedia.org/wikipedia/ commons/d/d0/Mosaic Floor_in_Synagogue_at_ Hammat_Tiberias_01. JPG (consultado el 24/02/2021) Praisethelorne, CC BY-SA $3.0<$ https:// creativecommons.org/ licenses/by-sa/3.0>, via Wikimedia Commons 
El tímpano griego, que indicaba la sacralidad del espacio del templo, es tomado por la tradición hebrea con un carácter similar, puesto que remite a un templo, el de Jerusalén, que sin embargo careció de él. Para reforzar esa idea de santidad, generalmente se inscribe el trazado de una venera en su interior, un motivo tomado de los sarcófagos romanos y de la cubierta de las hornacinas en algunas fachadas nabateas destinadas a cobijar a sus ídolos. Las puertas del armario santo son generalmente de casetones al modo romano, tal y como se representan las puertas del Templo en algunas monedas. Son, sin embargo, muy distintas de las de maderas ricas labradas con querubines y recubiertas de oro que debieron existir en el interior del edificio ${ }^{6}$. Los batientes bajo el tímpano quedan enmarcados por dos columnitas, habitualmente ofídicas, buscando una clara referencia a las columnas adelantadas en la fachada del Templo, conocidas como Jakim y Boaz.

Con estos elementos, los siglos del gótico y el Renacimiento construyen con sus líneas rectas un receptáculo para la Torá que el Barroco sin embargo quiebra, aunque los símbolos y el uso de una cortina protectora, dentro o fuera del mueble según los modos sefardíes o asquenazíes, permanecerán invariables. La relación entre esta cortina bordada y el mueble en sí nace de la proximidad, hasta el punto de hacerse equivalentes simbólicamente. La cortina o parojet suele reproducir con bordados la estructura de esta fachada a modo de portal de acceso al cielo ${ }^{7}$, pero esta idea de acceso al mundo de lo sagrado, de puerta que permite la visita a la divinidad, la encontraremos también repetida en los frontispicios de muchos de los libros publicados en los siglos del Barroco en los Países Bajos, donde adquiere el papel de portal a la sabiduría.

Cuando se configura en los mosaicos bizantinos de las sinagogas palestinas de los siglos IV al VI d. C. un arquetipo para la representación del Templo de Jerusalén, se está ofreciendo también un modelo de mueble para el arca de la Torá que lo transustancia en cualquier parte del mundo. Dios es albergado por el Templo y su ley lo es por un armario santo que resume en su apariencia los símbolos y referencias a esa arquitectura revelada.

El mundo hebreo era un mundo esencialmente nómada y nunca sintió demasiado apego hacia piezas de mobiliario voluminosas y difíciles de transportar. Los textos sagrados prestan poca atención a estos objetos domésticos que se describen siempre de un modo genérico, a diferencia de los que tienen un carácter sagrado, cuyo tratamiento y descripción son mucho más cuidados. Dios precisa absolutamente todo cuando ordena la construcción del templo: medidas, formas, materiales, procedimientos de ejecución de las piezas y espacios, no deja nada a la imaginación del ser humano. Se remarca de este modo la separación tajante entre la esfera de lo sagrado y lo profano. Así como en otros aspectos de la vida no hay separación con lo divino, en lo concerniente al mueble, la distinción de estos ámbitos, sagrado y profano, se mantiene tajante a lo largo de los siglos.

Solo la sinagoga muestra tipos específicos nacidos para dar respuestas a las necesidades del culto, como pueden ser este armario santo, la bimá o tarima que soporta el shulján o mesa para la lectura de la Ley o los diferentes tipos de bancos o safsalim utilizados. Algunos de estos bancos son hechos a modo de arcones para guardar los instrumentos personales de oración y resultan 
enajenables y tasados en función de la preminencia del sitio que ocupaban en la sala, tal y como muestran muchos documentos de compra-venta medievales ${ }^{8}$. Pero los muebles de casa, como el resto del ajuar, salvo en el caso de formar parte de las prácticas cultuales privadas, tampoco tuvieron una definición especial y respondían a los usos habituales en cada zona. No obstante, como muestra de ese carácter especial que les concede el judaísmo, que casi los convierte en seres animados, y que atañe a cualquier aspecto de la vida del ser humano judío, el mobiliario, como la casa entera, también era susceptible de convertirse en impuro (טמא-tamé), bien por asiento o bien por contagio.

Tras la destrucción de Templo, el estado de pureza (טהרה-tohorá), como en el caso del ser humano y otros útiles del ajuar doméstico, solo puede recuperarse mediante la inmersión en el baño ritual. La escena aparece en la Hagadá Hispanomorisca ${ }^{9}$ (folio 90 anverso, f90r), en ella unas mujeres introducen vasijas y copas en el baño ritual. La fiesta de la Pascua conmemora la salida de Egipto y el tránsito por el desierto. Su celebración, a la que se ligan las hagadot que más adelante habremos de considerar, exigía la pureza de cuerpos, enseres y espacios. Por este motivo, se aprovechaba la proximidad de la Pascua (Pésaj) para limpiar y sanear la casa y purificar muebles y objetos como la vajilla o los cubiertos habituales llevándolos al miqvé o baño ritual para su inmersión. También la Hagadá Dorada ${ }^{10}$ (f15r, Fig. 2) muestra las tareas de limpieza doméstica previas a la celebración de esta fiesta. Aún hoy es habitual ver en la calle durante los días previos a la fiesta muebles desvencijados y enseres inservibles y que por su estado serían susceptibles de impureza preparados para ser retirados y destruidos.

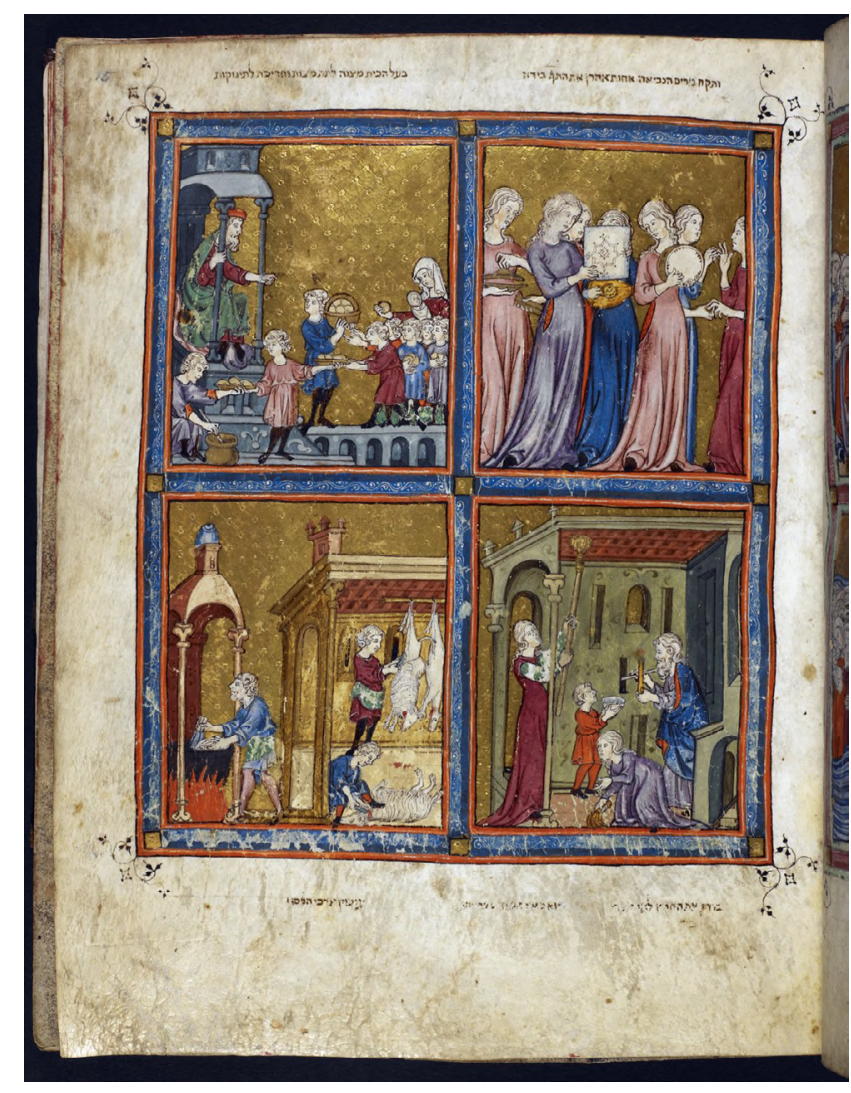

Fig. 2. Hagadá dorada, f15r. Preparación de la casa para Pésaj. British Library, Add. MS. 27210. Procedente de Cataluña, 1320 http://www.bl.uk/catalogues/ illuminatedmanuscripts/ILLUMIN ASP?Size $=$ mid $\&$ IllID $=57013$ (consultado el 24/02/2021) Unknown author, Public domain, via Wikimedia Commons 


\section{Las hagadot sefardies y sus ilustraciones}

La costumbre de narrar los hechos del éxodo en la Pascua se conoce desde época helenística, siglos III y II antes de la era cristiana. Respondía al mandato de Ex 13, 8 de explicar a los hijos el motivo de celebración de esa fiesta como muestra de la providencia de un Dios que saca a su pueblo de Egipto para conducirle a su tierra prometida. La presencia de hagadot en las casas judías nos habla no solo de la importancia del cumplimiento de un ritual doméstico, sino también del elevado nivel de alfabetización, especialmente entre los hombres que necesitaban la lectura para el servicio, pero no exclusivamente. Las hagadot hispanas eran libros específicamente hebreos a diferencia de las Biblias cuyo texto servía también a cristianos. Si las Biblias hebreas comienzan a producirse hacia 1230, manifestando una influencia islámica en la ilustración, las hagadot son un poco más tardías. Las primeras datan de finales del siglo XIII, pues en ese momento se separan definitivamente de los libros de oraciones como sidurim y mahzorim. Su carácter narrativo y didáctico exige una ilustración historiada ${ }^{11}$ que lo convierte en un libro de fácil manejo, con un tamaño reducido y eminentemente práctico.

El libro aseguraba que se mantuviese el orden durante el ritual doméstico y las imágenes servían para captar la atención de los niños en una ceremonia por lo general bastante larga. Habida cuenta de que su instrucción era precisamente el origen de esta celebración, es posible que se incluyesen textos variados procedentes de la Torá, del Talmud o de la tradición midrásica, mucho más interpretativa y dadora de sentido, que convirtiesen el acto en algo más pedagógico y ameno. Asimismo, la ilustración incitaba a la reflexión y la toma de conciencia de pertenencia a un pueblo con una historia real muy definida. Es probable que fuese también un libro usado en la sinagoga, como se infiere del hecho de que junto a la narración del éxodo se incluyesen además composiciones poéticas más propias del servicio en la sinagoga.

Con frecuencia eran judíos quienes traducían a la lengua romance el texto hebreo, generalmente a petición de un cristiano. Este fue el caso de Mosé Arragel de Guadalajara, que tradujo el texto original para el Maestre de la Orden de Calatrava, Luis González de Guzmán (1422). La interacción entre cristianos y judíos o entre cristianos y musulmanes en el capítulo del libro significó necesariamente colaboración e intercambio de ideas y motivos decorativos o imágenes. Llama poderosamente la atención el hecho de que en los libros hispanos hebreos la influencia sobre el aspecto visual parezca proceder más de Italia o Francia, pero esto podría explicarse por el hecho de que las muestras que nos quedan debieron ser producidas en comunidades cuya conexión con estas tierras europeas quedaba justificada por el sistema habitual de comunicación entre juderías y rabinos de todo el mundo: la correspondencia de pregunta y respuesta (sheelá-teshubá). Este sistema no solo permitía un contacto estrecho, también garantizaba una cierta unidad de criterio en la discusión y comentario, pudiendo servir de base incluso para la configuración de un particular gusto o visión estética.

La iluminación de libros constituye una de las muestras artísticas más personales del judaísmo medieval y moderno. Pese a sus contactos con 
la miniatura islámica o cristiana, la naturaleza ritual y privada de la mayor parte de estos documentos ilustrados (biblias, hagadot, rollos de Esther, sidurim, contratos matrimoniales) determina una expresión propia, lo que no es óbice para que, pese al carácter familiar de esta práctica, se produjese una estrecha colaboración entre miniaturistas de diferentes religiones en los mismos talleres ${ }^{12}$. Muchos de los motivos e imágenes procedían de un repertorio cristiano y naturalmente esto exigió un proceso de reinterpretación desde el judaísmo que conlleva la creación de un propio imaginario hispanojudío. En Sefarad, tal archivo temático hunde sus raíces en la interpretación midrásica y la influencia centroeuropea se hará patente a través de círculos como el de Nahmánides o Bahya ben Asher ${ }^{13}$. Esta diferencia mostraba la controversia entre dos facciones culturales sefardíes que podría estar detrás de las variaciones conceptuales y estilísticas apreciables, más allá de lo atribuible a la mano de cada autor: una elite apegada a la tradición judeoislámica y otra más afín a la expresión cristiana y el judaísmo centroeuropeo.

Ciertamente es este un tema complejo y el reconocimiento de una personalidad propia a la miniatura judía no es un lugar coincidente entre los investigadores ${ }^{14}$. Estos prefieren hablar de miniatura hebrea en relación al país que acoge la comunidad, negando así la existencia de algo específico y alimentando una discusión tan antigua como el debate sobre la naturaleza del arte judío, nacido con la atención de Müller y Schlosser a la Hagadá de $\operatorname{Sarajevo}^{15}(1898)^{16}$. Sin embargo, la necesidad de distanciarse de ese contexto conduce a iluminadores y escribas a separarse críticamente de él. Ambos componen una especie de catálogo en que evidencian las distintas maneras de concebir la imagen en Sefarad y el mundo asquenazi. El trasiego de motivos iconográficos y estilísticos con el entorno no judío fue abundante, pero no hubo un contacto muy estrecho entre los propios creadores judíos de ambas regiones ${ }^{17}$, pues las diferencias son bastante evidentes.

La influencia de la iluminación de textos musulmanes prevalece en la mayor parte de la península, pero es menor en la decoración de textos hebreos procedentes del área catalana, lógicamente a causa de la escasa presencia que el mundo islámico tuvo en esta región. Si las biblias hebreas se impregnan del gusto geométrico tradicional, nazarí18 o mudéjar, la hagadá, al requerir figuración para reforzar su carácter narrativo, acude en demanda de ayuda a modelos preferentemente cristianos. Esto origina una coincidencia parcial de ciclos y motivos iconográficos, pero las hagadot no copian obras del entorno, aunque el entorno, incluso arquitectónico, le sirva de inspiración. Realmente parecen crear un lenguaje propio y diferenciado a partir del mismo, pero acudiendo siempre a la propia tradición iconográfica que emana de los comentarios rabínicos o de una memoria artística colectiva que surge del bizantinismo de Dura Europos (244-245 d. C.) o la musivaria de las sinagogas palestinas (siglo VI).

Es el propio iluminador el que vierte en su obra toda su formación artísticamente híbrida, de manera que las diferencias estilísticas entre ejemplos de zonas similares pueden atribuirse a este hecho. No obstante, existen argumentos opuestos a los expresados por Katrin Kogman-Appel que aboga por la judeidad de los decoradores. Joseph Shatzmiller ${ }^{19}$, por ejemplo, interpreta ciertos errores iconográficos en las hagadot hispanas como prueba del desconocimiento 
del miniaturista que hacen pensar que la colaboración con decoradores cristianos fue más habitual de lo estimado. Efectivamente, que en el revés del folio 42 (reverso del folio 42, f42v) de la Hagadá Kaufmann ${ }^{20}$ aparezca una mujer sentada junto a un hombre en un servicio religioso llama la atención y que en el f59v de esta misma hagadá o el f10v de la Hagadá Dorada se represente a un ser angelical con un halo, resulta igualmente extraño en la tradición hebrea. La colaboración cristiana podría servir de ayuda para explicar la aparente aculturación, si es que consideramos que en la Hispania medieval convivieron culturas diferentes, o simplemente podría explicar hasta qué punto existió un modo común de entender la imagen y el valor de la iconografía, a la que bastaba con alterar su significado en el momento de la lectura. En el campo del mueble que nos ocupa tal vez esa colaboración podría explicar también que no exista diferenciación con el mobiliario representado en otros códices miniados cristianos o islámicos.

La arquitectura de la zona se hace presente en las hagadot a través de la recreación de ciudades y edificios, pero también a través del diseño de los muebles. Generalmente se utilizan soluciones góticas, aunque se trate de un gótico sosegado y bastante lineal, como requiere el contorno del dibujo. La impresión visual tal vez esté motivada por la mezcla de lo francés con un clasicismo italiano, aunque no parece existir inconveniente alguno en la mezcla con elementos estructurales y decorativos islámicos. La representación del trono del faraón o de los sitiales que sirven de asiento a las grandes figuras rabínicas como Eliezer o Aquiva constituye una muestra de esta inspiración. Frecuentemente el diseño de este mueble varía dentro de la misma obra en un alarde de variación formal. Las hagadot sefardíes del siglo XIV en comparación con las asquenazíes del XV, como la Hagadá Asquenazí ilustrada por Joel ben Simón (1430-1470, Add MS 14762, British Library) ${ }^{21}$, no prestan tanta atención a la representación detallada del mobiliario. Probablemente esto no se debe a la diferencia estilística o iconográfica, pues los muebles representados siguen siendo básicamente los mismos y de diseños similares. El repertorio, no obstante, parece enriquecerse en solo unas décadas como muestra esta hagadá germana y pronto recogerá armarios (f1v) o atriles en forma de estantería (f7v). Lo interesante es el detalle que se presta a estos objetos, a las molduras y elementos que componen su decoración. Es muy probable que esto refleje una forma distinta de vida, quizás no más estable, pues los judíos centroeuropeos también sufrían ataques y persecuciones, pero sí con un mayor apego al carácter estético y placentero y no solo utilitario del objeto. El mobiliario medieval hispano es esencialmente práctico, polivalente y reducido.

Se conservan unos quince ejemplares de hagadot sefardíes y para este análisis se han comprobado las ilustraciones de solo once de ellas ${ }^{22}$. Las hagadot hispanas más significativas, las de Sarajevo, Barcelona, Rylands y Kaufmann, proceden de Cataluña y son un claro testimonio de este ambiente de intercambio cultural que fue la Hispania medieval. Franco Mata relaciona la Hagadá de Sarajevo con posibles influencias del taller de Ferrer y Arnau Bassa o Ramón Destorrents, pero sorprendentemente la pone también en conexión con las imágenes de la cerca exterior de la sillería del coro de la catedral toledana ${ }^{23}$, señalando por ejemplo la extraordinaria importancia que se da en el programa 
iconográfico toledano a los episodios de las plagas de Egipto ${ }^{24}$. Es probable que en el taller de los Bassa trabajase algún colaborador judío, como Levi bar Isaac, que plasmase su huella y modo de entender el arte desde una óptica puramente judía ${ }^{25}$, pero la impronta del lujo buscado denota un deseo de asimilar el producto a los ricos libros cristianos. Las imágenes de las hagadot nos ofrecen una visión bastante nítida de los modos de vida y de las formas del ritual adoptados por sus usuarios. No cualquier familia judía podía permitirse una hagadá ilustrada y su valor se desprende del contenido de muchos testamentos judíos donde se detalla minuciosamente el tipo de libro, su título y el heredero destinatario. Tal vez uno de los mejores ejemplos de este discurso nos lo ofrezca la Hagadá de Sarajevo (c. 1325-1350). Este libro utiliza pergamino, piel de becerro blanqueado, pan de oro y cobre y cuenta con 109 páginas de las que solo 34 presentan imágenes a página entera y sin texto. Dichas páginas ilustradas aparecen agrupadas, pero las imágenes mantienen escasa relación con el texto litúrgico. Sin embargo, junto con la Hagadá Prato ${ }^{26}$ (c. 1300) es la única que incluye el libro del Génesis antes del Éxodo. Las imágenes de la creación hablarían de esa conexión con la iluminación cristiana, pues este tipo de figuras a página entera es más habitual en las biblias cristianas medievales. Al modo judío, sin embargo, no se incluye imagen alguna de Dios en ese acto de la creación.

La Hagadá de Sarajevo incluye además la representación de figuras masculinas ataviadas al modo judío usual en la Corona de Aragón, con la cabeza cubierta por una capucha ${ }^{27}$, pero quizás resulta más interesante por contener una representación del séder y del interior de una sinagoga, ya que ambas imágenes nos ofrecen alguna información lateral sobre mobiliario. El iluminador demuestra su perfecto conocimiento y familiaridad con el ritual ${ }^{28}$ y sitúa al padre de familia en un trono en un lugar preferente de la mesa, enfrentado al invitado, también en un sillón, mientras la madre e hijos se disponen a un lateral de la mesa frente al lector-espectador.

La Hagadá de Barcelona (c. 1340) está compuesta por 161 folios que debieron ser realizados en dos épocas y lugares diferentes, las ilustraciones se reparten a lo largo de todo el texto. La parte central más antigua debió confeccionarse en Cataluña en el siglo XIV (folios 9-151). El resto, que se añade en Provenza, pertenece también a finales del siglo XIV ${ }^{29}$. En la Hagadá Rylands ${ }^{30}$ (c. 1330-1349) las ilustraciones aparecen dispersas después de la parte que presenta la narración de la Pascua. Junto a las hagadot Hispanomorisca (c. 1300), Sister o Hermana ${ }^{31}$ (c. 1325-1335), Brother o Hermano ${ }^{32}$ (c. 1330) у Kaufmann, de mediados del siglo XIV, todas nos ofrecen ricos ejemplos de muebles, de su uso y de su significado simbólico. Otras hagadot son mucho más parcas en muestras de este tipo, aunque resulten igualmente interesantes para dilucidar el tema. Es el caso de la Hagadá Graziano ${ }^{33}$ (c. 1300-1328), la Hagadá Sassoon (c. 1320) o la Hagadá de Poblet, de finales del siglo XIV.

El Edicto de Expulsión de 31 de marzo de 1492 prohibió que los judíos llevasen consigo todo tipo de bienes, pero no prestó mucha atención a los libros por su escaso valor crematístico y, aunque en realidad quedaban inmovilizados e intervenidos ${ }^{34}$, muchos de ellos, de carácter sagrado y litúrgico, fueron sacados de Sefarad y diseminados por las circunstancias históricas. No obstante, como señala la Dra. Cano, junto al uso de las quaterna o cuadernillos de ocho páginas 
que componen el libro, hay en los códices sefardíes una técnica que se usa desde fines del siglo XIII y que permite adscribir fácilmente estos manuscritos a los diferentes talleres hispanos, pues se señalan los renglones y los márgenes de la página, lo que no es habitual en los talleres provenzales, por ejemplo ${ }^{35}$.

\section{Consideraciones previas sobre conceptos artísticos, estéticos e iconográficos}

El concepto hebreo de belleza, definido ya en el texto bíblico, se mantuvo omnipresente a lo largo de la historia del arte judío. El peso de lo religioso en la tradición hebrea afecta a cualquier manifestación y, por supuesto, también al mobiliario. Este concepto aplicado a la práctica manual implica el respeto al valor de la practicidad y al necesario reflejo de lo divino en cualquier producto humano como referencia suprema posible. La insistencia en la representación de los instrumentos empleados en el servicio del templo en las biblias medievales constituye una muestra de ese concepto trascendente de la belleza de Dios en los objetos realizados por el hombre. Estos adquieren dignidad en el servicio a la santidad y la gloria de Dios. Es el concepto de belleza como kebod, reflejado en la creación natural de todo lo existente y depositado por el artífice humano en los objetos que hace como respeto a esa grandeza divina que trasciende. El respeto deriva del uso de los materiales más ricos y adecuados como ofrenda a la naturaleza de Dios, pero también del uso del adorno como complemento ${ }^{36}$. El adorno no molesta a la esencia en absoluto, antes bien, es un complemento potenciador de la misma. Materiales y decoración también determinan la belleza del mueble.

No obstante, la belleza recreada por el hombre en honor de su Dios no puede estar completa si su manufactura no ha sido dirigida por la sabiduría del corazón (Ex 35, 35), la habilidad y el conocimiento precisos que, puestos por Dios en la voluntad del artesano, dirigen y controlan todo el proceso. El Judaísmo ha tenido a lo largo de su historia una relación complicada con las artes plásticas, pero es el propio Dios quien instituye el privilegio de los artesanos (Ex 31, 1-11) liberando su habilidad de cualquier sospecha de práctica idolátrica, puesto que queda restringida a su servicio. Hacer muebles, especialmente para el culto de la sinagoga, pero también los domésticos, constituye una tarea similar a la de revestir el Templo de Jerusalén. Es en sí mismo un acto de glorificación. En Si 38, 24-34, se hace hincapié, no obstante, en que el tipo de sabiduría artesanal requerido se basa en la confianza en la habilidad manual y la experiencia y nada tiene que ver con la sabiduría de los jueces y los profetas. Este conocimiento no pertenece al tipo superior de sabiduría requerido para el gobierno de Israel, que implica la actividad del estudio y la meditación y nace de la reflexión y los ratos de ocio que la permiten.

Es por este motivo que cualquier vínculo medieval con la artesanía litúrgica sagrada constituye no solo una justificación de esa actividad, sino también un acto legítimo de búsqueda de inspiración iconográfica o de dotación de significado. Pese a la reticencia a reproducir cualquier imagen tridimensional de esos objetos, su memoria se hará presente en el diseño de muebles y objetos dedicados a glorificar a Dios, aun en ausencia de su Templo. El mobiliario del 
Templo es en realidad resultado de la experimentación con el culto durante el Éxodo en el mishkán mequdash o santuario móvil. El mobiliario y objetos del tabernáculo aparecen descritos en los capítulos 25 a 40 del libro del Éxodo. Estos textos se convierten en referencia simbólica expresa para la historia del mueble sacro hebreo posterior.

La imagen del Templo se había convertido en un estereotipado conjunto de fórmulas sin variación. El propio tabernáculo, el arca de la Alianza, la menorá, los altares del incienso y del holocausto, la mesa de la presentación y otros objetos aparecen descritos y representados con idéntico aspecto átono. Constituyen, no obstante, una inestimable fuente de inspiración para la factura del mobiliario litúrgico, tanto cristiano como judío, desde su aparición. Como señala K. Kogman-Appel ${ }^{37}$, la representación de estos muebles y objetos en las biblias españolas es habitual, aunque siempre se busca una imagen sin volumen, estrictamente plana, especialmente en las catalanas, como la de Perpignan (1299). Sin embargo, en ellas estos motivos aparecen representados en total descontextualización y sin referencia espacial, casi como símbolo de un tercer templo mesiánico o como indicio de que la Biblia es considerada en sí misma un pequeño templo al que se accede abriendo las puertas de su cubierta. Este valor enriquece el significado del mobiliario de culto sinagogal.

Hay en ellas una mayor presencia de elementos góticos en comparación a las otras biblias peninsulares. La precisión en la representación de estos objetos debe entenderse como una intención de mantener intacto y fijado para la eternidad el ritual empleado en el servicio a Dios. El texto sagrado marca las diferencias de consideración de estos objetos en comparación con otras religiones. De esta manera, el arca de la Alianza, un mueble donde guardar las tablas del pacto, adquiere casi el carácter de estatua de culto y ocupa el lugar, ya en el santuario móvil, ya en el Templo, que otras creencias le consagran ${ }^{38}$ a estas imágenes.

Hemos de tener presente la expresa prohibición de representar imagen alguna de Dios en la tradición hebrea, de modo que el arca se transforma en un símbolo sustitutivo respetuoso y adecuado, aunque el efecto sea el mismo. En realidad no es más que un arcón de 2'5 x 1'5 codos, chapado en oro y transportado gracias a dos barras pasadas a través de cuatro anillas en las esquinas. El propiciatorio aparecía a modo de tapa, constituido por dos querubines afrontados cuyas alas protegían toda la estructura. Hay, sin embargo, algo que lo transforma en mucho más que un mueble y esto es sin duda la santidad de que le inviste el hecho de ser receptáculo del símbolo sagrado por antonomasia, la Ley $^{39}$.

Existían diferentes tipos de altares y algunos rozaban los límites de la arquitectura abandonando los de la carpintería. El de los holocaustos (Ex 37 1-2, Ex 38 1-2) estaba chapado en bronce, era más largo que alto y en sus esquinas había cuatro prominencias en forma de cuerno. Corresponde al tipo habitual en Meggido durante el siglo X a. C. Por el contrario, el del incienso (Ex 30 1-5, Ex 37 10-15) era más alto que ancho, recubierto de oro, con una moldura circundante también en oro y cuatro anillas para pasar las barras que permitían su transporte. 
La mesa de la presentación para el pan de la ofrenda era de madera de acacia también chapada en oro, con una moldura circundante y también cuatro anillas para su transporte con barras (Ex 35 23-29, Ex 37 10-15).

Lo que llama la atención y contrasta con el carácter nómada del pueblo hebreo en este momento es el uso de materiales costosos como el oro y las ricas maderas. Esto se ha explicado aludiendo a que se trata en realidad de textos añadidos en el siglo V a. C. cuando tiene lugar la revisión sacerdotal en el exilio babilonio. Las primeras representaciones de estos muebles de que tenemos constancia proceden de la sinagoga de Dura Europos (siglo III) y de algunas biblias orientales del siglo X, por lo que hay un margen temporal considerable para crear y fijar una iconografía precisa que si bien tuvo un indudable origen judío, será usada y ligeramente transformada por la cristiandad paleocristiana y medieval.

Algunos de estos objetos muebles sufren una redefinición a partir de la época helenística. Los mosaicos de las sinagogas bizantinas de la Galilea muestran un arca que ha evolucionado ya hacia el tipo de armario para la Torá que se usará en las sinagogas europeas desde la Edad Media. La variación tipológica tiene una explicación religiosa, pese a que se mantenga el nombre para ambos muebles. La sinagoga jamás puede sustituir al Templo, pues la presencia divina tiene su sede en él, de manera que ni siquiera es un sustituto equivalente, pues se trata simplemente de un espacio de reunión fuera de Jerusalén. El arca indica ese compromiso divino de presencia eterna en medio de su pueblo, pero el armario sinagogal se ha construido en referencia precisamente a esa realidad y debe recordar el Templo, aunque en ningún momento es receptáculo de la esencia divina, que solo se persona en medio de su comunidad mediante la oración y un extraño fenómeno de translocación que convierte el suelo de la sinagoga en el sagrado suelo de Jerusalén ${ }^{40}$. Pero esta construcción a modo casi de anagrama sigue presente desde la Antigüedad y la vemos aparecer en las páginas de la Hagadá de Sarajevo donde se presenta como imagen del arca de la alianza (f33v) o en los diseños barrocos de armarios santos para sinagogas o las cortinas que ocultan a la Torá en ellos alojada.

\section{El mueble doméstico y litúrgico hispanojudío en las hagadot. Tipos y variaciones}

Se conservan pocos muebles medievales, pues a menudo, si estaban adornados con ricos materiales como el marfil, eran objeto de rapiña o se desmontaban, por otro lado la conservación de la madera no siempre fue la adecuada. Los conocemos en buena medida por las representaciones en los libros. Estas nos permiten comprender los rasgos estilísticos predominantes de cada época, así sabemos que algunas sillas bizantinas se concebían como arcas con respaldo que adoptaban una decoración arquitectónica que jugaba con el arco de medio punto o que muchos de los muebles sagrados o áulicos se adornaban con tallados fitomórficos y animales muy próximos a los representados en las miniaturas ${ }^{41}$.

El mobiliario no era abundante en las casas hispanas y algunas piezas eran eminentemente funcionales y de servicio ambivalente: arquibancos, esto es, asientos de silla a modo de arcones, escaños y bancos que podían hacer las 
veces de cama o diván, mesas de fácil montaje y desmontado... El mobiliario cumplía unas cuantas tareas básicas: almacenar, permitir el descanso y facilitar el trabajo artesanal y las actividades cotidianas como la comida. La polifuncionalidad imponía la sencillez formal dando mayor importancia a la estructura, pero poniendo el acento hedonista en el adorno y recubrimiento con ricas y coloridas telas. El mueble necesitaba el recurso al textil para adquirir la majestuosidad exigida por la celebración: una mesa requería de un rico mantel para un banquete especial como podía ser la cena de Pascua, pero el mismo paño se convertía en sí mismo en un indicador del estatus familiar. La mayor parte se concentraba en las estancias nobles y privadas, generalmente alejadas de las cocinas y aisladas con paredes enteladas y suelos alfombrados, si la familia podía permitírselo.

El recurso a las telas para tapizar paredes y aislar las estancias del frío era común a todo el mundo hispano, cristiano o andalusí, a tenor de los diversos inventarios domésticos y las detalladas descripciones testamentarias al margen de la religión de dueños y testadores o herederos. Los interiores judíos seguían probablemente la costumbre habitual en el entorno, el grado de sincretismo debía ser alto en toda la península ${ }^{42}$ y mobiliario y decoración debían de tener bastantes puntos en común. La representación de interiores en los manuscritos medievales testimonia este grado de intercambio a través de la iconografía, pues no deja de ser sospechoso que determinados personajes como el faraón sean representados de manera similar en manuscritos musulmanes, hebreos o cristianos ${ }^{43}$.

La hagadá narra básicamente la historia de un éxodo por el desierto y las escenas dibujadas transcurren en su mayoría al aire libre, las pocas localizaciones de interior que arrojan información sobre muebles corresponden a unas pocas acciones repetidas en casi todas ellas: Jacob bendiciendo a Efraím y Manasés desde el lecho, Moisés y Aarón ante el faraón, la muerte de los primogénitos, la celebración del banquete pascual, el servicio sinagogal... Es esto lo que determina el limitado repertorio tipográfico que podemos extraer de sus imágenes, reduciéndose principalmente a distintos tipos de asientos, diferenciados según la categoría del personaje que hace uso de ellos, desde el faraón a los rabinos, quienes a veces aparecen en sus scriptoria o sentados leyendo ante diferentes tipos de atriles. Se representan también varios tipos de lechos, mesas para la celebración de la cena pascual y algunos cofres y cajas, muchos de ellos habilitados también al parecer como asientos. La imagen de estas hagadot de los siglos XIII y XIV no suele ser precisa, no busca el detalle, y en ocasiones hemos de acudir a la descripción que de tales muebles se hace en testamentos e inventarios de propiedades de la época.

Los asientos representados en las hagadot hispanas corresponden a tipos muy diferentes que oscilan desde lo más básico, como pueda ser un simple cajón, a un trono real configurado como estructura arquitectónica. Varían en función de los ciclos iconográficos y también, en cierto modo, de la hagadá en cuestión, aunque cronológicamente la distancia entre todas ellas no sea lo suficientemente significativa como para generar una variación importante. La silla sobre la que aparece sentada la figura del sabio (f5a) en la Hagadá Prato (c.1300-1450) es un trono simple sobre un estrado, muy similar al utilizado en 
la Hagadá Graziano (1300-1328) para asiento del rabí Gamaliel, salvo que se le añade un atril y el estrado es decorado en el frente con una galería de arquitos trilobulados. La presencia del estrado es un signo de autoridad ya intelectual ya terrenal, pues se utiliza solo en las figuras sedentes del Faraón o los grandes rabinos. No obstante, en el f15r de la Hagadá Dorada (c. 1320) es el propio dueño de la casa quien aparece ordenando la distribución de la matsah y el haroset a los niños y sentado bajo dosel en un trono alto de estructura arquitectónica que se alza sobre un estrado de dos pisos.

El estrado doble, privativo de los monarcas, se convierte pronto en una iconografía válida en los códices de todas las religiones peninsulares, así se representaba también al faraón, sentado a la occidental, con los pies apoyados en el suelo y sobre un estrado de dos peldaños, en los folios 4v y $5 \mathrm{v}$ del Sulwam al muta ${ }^{44}$. No obstante, algo más adelante, en los folios 10v y 11r, el faraón es dibujado con las piernas cruzadas, un gesto que no es habitual en un monarca cristiano. Es posible que este detalle sea una convención para acentuar el orientalismo del personaje, una señal utilizada por el segundo pintor de esta hagadá, mucho más avezado en las soluciones del gótico francés que el primero y cuya mano llega tan solo hasta el folio anterior. Este apego a soluciones más modernas se observa también en el baldaquino arquitectónico que cubre el trono del faraón y en la búsqueda de una solución espacial más adecuada a las leyes de la perspectiva propias de la pintura italiana prerrenacentista.

En el repertorio de asientos de esta hagadá domina el trono con dosel y estructura arquitectónica, pero hay algún caso en que los propios personajes parecen sentarse en el aire y ocultan el mueble con sus vestidos (f8v) o bien un paño lo envuelve todo, como es el caso de la cátedra simple en la representación del faraón inmovilizado por la oscuridad (f13r) mientras los israelitas roban muebles y copas de los egipcios. Es, por cierto, este el único caso en que se representa lo que podría ser un aparador para copas muy simple, a modo de bargueño cuya parte inferior se ha convertido en un piso con arcos de medio punto. En la Hagadá Hispanomorisca (c. 1300) este mismo tema se aloja bajo un trilobulado arco gótico (f9v) que podría insinuar la casa de los egipcios, pero el ladrón de las copas no las extrae de ningún mueble, demostrando la escasa importancia que tiene en los hechos este detalle. Por el contrario, en la Hagadá Brother (f6r), ni siquiera aparece ese marco arquitectónico. Igualmente, podemos ver sentado a Jacob (f5r) en una cátedra con estrado independiente similar a una silla de tijeras cubierta con un paño rojo, mientras José cuenta sus sueños y este le reprende.

El respaldo y el torneado de los brazos de un asiento le imprimen valor y significado, aunque también lo hace el apego a la tradición y la repetición de modelos clásicos de la antigüedad. Las cátedras, por ejemplo, con respaldo o sin él, forman parte desde el principio de la liturgia sinagogal. Las cátedras de Moisés en las antiguas sinagogas, como aún pueden verse en Khorazim o Delos, eran ocupadas por los rabinos que comentaban las lecturas. La idea de esta silla como trono de sabiduría perduró y de hecho su forma es la que parece reproducirse en las diferentes representaciones de los grandes rabinos como Aquiva (f15r) o Gamaliel (f17r), así aparece en la Hagadá Brother (c. 1330), aunque la silla que ocupa Gamaliel desarrolla un respaldo de dos pisos con arcos de medio 
punto y un friso de arquitos lombardos como remate, cuyo diseño parece inspirarse en los sitiales de coro de las catedrales cristianas. La estructura envuelve a Gamaliel convirtiéndose de este modo en una especie de pupitre o scriptorium. Mucho más simple es la cátedra ocupada por Gamaliel (f25r, Fig. 3) en la Hagadá de Sarajevo (c. 1325-1350). Se trata de una silla de respaldo alto similar a la cátedra del obispo Maximiano de Rávena (siglo VI), pero sin decoración alguna, aunque marca igualmente la autoridad frente a unos alumnos que se disponen en bancos sobre una tarima de madera. Es la oposición entre estos dos tipos de muebles la que acentúa la diferencia de rango entre maestro y estudiantes, algo que también sucedía en otros ámbitos como la corte o la misma sinagoga, donde la silla era propiedad enajenable y su valor quedaba determinado por la proximidad a los núcleos litúrgicos fundamentales y en parte, por la categoría de los propietarios vecinos. Por el contrario en la imagen dedicada en el margen derecho del folio 34v de la Hagadá Sister (c. 1325-1335) a Eliezer ben Azaria, este aparece sentado sobre un simple trono sin respaldo pero con estrado y ante un atril que sostiene sus escritos y notas.

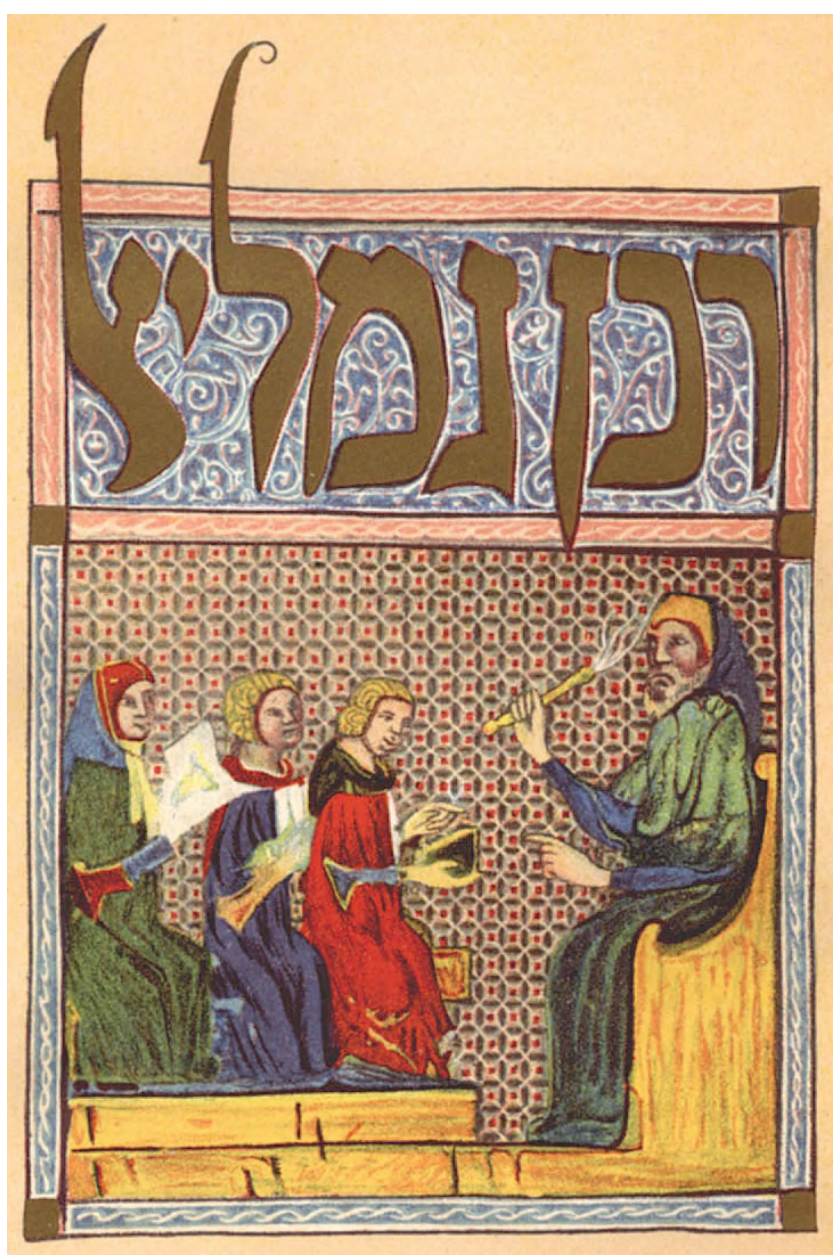

Fig. 3. Hagadá de Sarajevo, f25r. El rabino Gamaliel impartiendo enseñanza. Zemaljski Muzej Bosne i Hercegovine, Procedente de Cataluña, c. 1325-1350.

http://www.bl.uk/catalogues/ illuminatedmanuscripts/ILLUMIN. ASP?Size $=$ mid\&IllID $=57013$ (consultado el 24/02/2021) Unknown author, Public domain, via Wikimedia Commons

La representación del hijo sabio, junto al malvado que blande una espada y está en pie, que se hace en el folio 35v también le muestra sobre un trono con estrado. Sin embargo, en esta hagadá las imágenes de los dueños que 
dirigen el séder en los folios $27 \mathrm{v}$ con la primera copa de bendición y en el folio $51 v$ con la matzá en la mano aparecen sentados sobre asientos tipo arcón sin estrado alguno. En la Hagadá Kaufmann (mediados del siglo XIV), estos personajes ni siquiera se representan sentados. Podríamos deducir de este hecho que el estrado es evidentemente un signo de autoridad intelectual, pero en la Hagadá Kaufmann, por ejemplo, el hijo sabio (f18r) se presenta sentado sobre un taburete de cuatro patas, con los pies apoyados directamente en el suelo, un pequeño libro en la mano derecha y la izquierda alzada en señal de prédica. Curiosamente es el mismo tipo de silla que ocupa el hijo simple (f19r), peo este no porta libro en su mano. El hijo malvado (f18v) por el contrario sigue apareciendo en pie, esta vez con escudo y lanza. El estrado puede ser símbolo de autoridad política e intelectual, por lo que para una mayor precisión es probable que se acuda a reforzar el mensaje con otro tipo de actitudes o atributos.

Otro de los muebles que aparece frecuentemente en las ilustraciones de las hagadot es el lecho. Los diferentes tipos de cama que ilustran las escenas de la muerte de los primogénitos o de las bendiciones de Jacob y de José varían desde los simples lechos con mantas a las camas con dosel y cortinajes. Representan ciertamente los tipos de cama propios de los siglos XIII y XIV. En la Hagadá Brother los primogénitos (f6r) parecen yacer directamente sobre el suelo pero una especie de dosel de arquitos podría insinuar la estructura lignaria de la cama o bien podría tratarse de un marco arquitectónico doméstico, como sucede en la Hagadá de Sarajevo (f26r) donde los primogénitos aparecen cubiertos por una manta bajo un arco de medio punto que serviría de perfil a una cubierta cupulada. En la Hagadá Sister o Hermana (f16r) no hay marco arquitectónico y el lecho se coloca directamente sobre el suelo, pero en la Hagadá Hispanomorisca (f82v) la cama sí presenta un bastidor indicado por las patas torneadas de madera o de metal. En la Hagadá de Sarajevo (f9v), en otra muestra de la variedad de soluciones, Rebeca da a luz sentada sobre un lecho cuyo volumen solo se adivina bajo un paño blanco y sin embargo el tema de Isaac bendiciendo a Jacob, en que al primero habitualmente se le representa en cama, como sí sucede en la Hagadá Hermana (f7r), opta en este caso por un Isaac sedente en un trono de alto respaldo que parece continuarse en una cubierta semiesférica en forma de ábside ${ }^{45}$.

Se trata del mismo trono representado también en el folio 10r cuando Esaú se presenta ante Isaac. No es un recurso frecuente en las hagadot, que suelen variar la confección del mueble aún en ilustraciones contiguas. Sospechamos que hay en eso una expresa intención simbólica, pues recordemos la importancia que este tipo de espacio cubierto, propio de las basílicas romanas y armarios santos de las sinagogas primitivas, tiene por su carácter sagrado y su vínculo con la ley que alberga. La estructura de trono con hornacina aparece claramente en la Hagadá Dorada (f3r) para dibujar un tema puramente medieval y no recogido en la tradición antigua como el del rey Nimrod, bisnieto de Noé, que persigue a Abraham y lo condena a un fuego del que sale indemne, antes de proceder a la construcción de la torre de Babel. Teniendo en cuenta el carácter de la figura no deja de extrañarnos el uso de este mueble con sus connotaciones sagradas. 
En otras páginas de la Hagadá de Sarajevo, dedicadas a la historia de José y en las que se representa el episodio de sus sueños (f11v) y los del faraón (f14r), ambos personajes aparecen tendidos y cubiertos por una colcha de bordes púrpura que dibuja perfectamente el volumen del lecho elevado del suelo ${ }^{46}$ (Hagadá Sister, f7v, Fig. 4). En la Hagadá Dorada (f5r), el sueño de las gavillas de trigo inclinadas nos muestra a José en una mullida cama de ropa blanca, cubierta con una frazada púrpura y una gran almohada de borlones en las esquinas. La cama de ropa carecía de bastidor y se componía de varios colchones y cubiertas superpuestos, sobre los que se dormía ligeramente incorporado ${ }^{47}$. Un almohadón dorado de inspiración islámica y de forma similar sirve de apoyo a Jacob, que postrado en la cama, bendice a los hijos de José (f8v, Fig. 5).
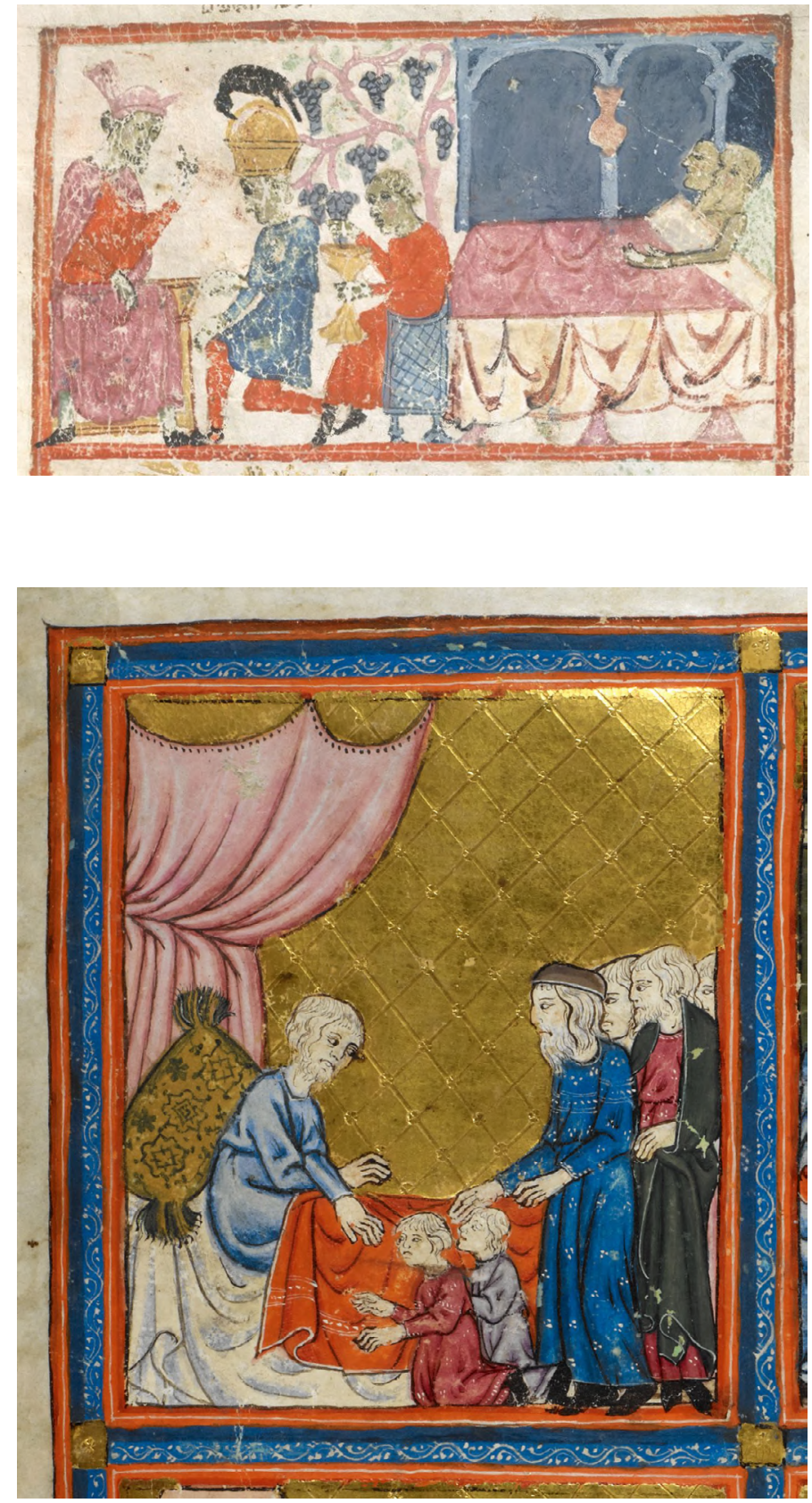

Fig. 4. Hagadá Sister, f7v, detalle. Sueño del copero y el panadero del faraón. Procedente de Cataluña, c. 1325-1350. https://upload.wikimedia.org/ wikipedia/commons/3/33/Dreams_ of_the_butler_and_the_baker. jpg (consultado el 24/02/2021) Unknown author, Public domain, via Wikimedia Commons

Fig. 5. Hagadá dorada, f8v, detalle. Jacob bendice a Efraín y Manasés. British Library, Add. MS. 27210. Procedente de Cataluña, 1320. http:// www.bl.uk/catalogues/ illuminatedmanuscripts/ ILLUMIN.

ASP?Size $=$ mid $\&$ IllID $=57210$ (consultado el 24/02/2021) Illustrator of the Golden Haggadah, Catalonia, Public domain, via Wikimedia Commons 
El gesto de la bendición ha sido objeto de muchísimos comentarios, pues Jacob cruza su mano para bendecir a Efraín en primer lugar, mientras José parece indicar que es Manasés, como primogénito quien debe ser bendecido antes. Lo interesante del lecho de Jacob es que en este caso, pese a usar también ropa blanca bajo cubierta roja, intuimos que son colores vinculados al poder, la cama se cubre con cortinajes, casi como si se tratase de una cama encajada. La cortina fue un elemento que se extiende por Europa desde Bizancio principalmente ${ }^{48}$, por lo que se inviste de un cierto halo de trascendencia. En Bizancio era empleada para delimitar espacios áulicos, pero también sagrados en las iglesias, por este motivo su empleo doméstico no solo remite a la idea de poder, jerarquía o categoría, pues de alguna manera sacraliza la atmósfera que envuelve. Las cortinas del lecho de Jacob materializan la importancia y la trascendencia del personaje al mismo tiempo.

En la Hagadá Hispanomorisca (f64r) la parturienta israelita, cuyo hijo varón es tomado por un sirviente del faraón para ser arrojado al Nilo, yace en un lecho con cabecero y pie de sólidas patas de madera y cubiertos ambos por lienzos rojos, pero sin forma ni volumen que permitan adivinar el bastidor del mueble.

Las mesas representadas en estas hagadot son estructuras medievales muy simples, tablas sobre burros o borriquetes disimulados por la mantelería en algunos casos, como se puede apreciar en la Hagadá de Barcelona (c. 1340), donde las patas de la estructura quizás desmontable aparecen bajo el rico mantel blanco con cenefas azules de motivos geométricos (f19v y f28v) o ajedrezados combinados con alguna estrella de David y siluetas de animales (f17v). En las escenas de las que son centro, observamos que el lugar de asiento es importante y que al modo tradicional uno de los lados largos suele quedar sin comensales para facilitar el servicio. Generalmente se representan sobre la mesa las propias hagadot utilizadas por los comensales junto a las copas de bendición. El padre de familia que dirige el séder suele colocarse en un extremo, el invitado de honor en el otro y el resto de la familia en el lado largo exterior. Las sillas del anfitrión y el invitado suelen presentar respaldo y brazos torneados, el resto puede ocupar sillas o bancos (f28v). No obstante en algunas ocasiones aún se observan restos de una tradición medieval muy anterior, la del anfitrión sentado a una mesa distinta más pequeña, como es el caso de la escena del banquete de José con sus hermanos que aparece en la Hagadá Sister (f9v). José predice el futuro en una copa, tal vez en una estancia contigua. En esta otra hagadá las mesas parecen planos suspendidos en el aire, no se representa su estructura y las patas no aparecen dibujadas bajo los paños. Llama la atención, por su absoluta modernidad, la mesa redonda sobre pie torneado a la que se sientan Rabí Aquiva y sus discípulos en la Hagadá Kaufmann, pues este tipo surge al parecer en la Baja Edad Media ${ }^{49}$.

El éxodo no es un tema apropiado para interiores y menos de carácter sagrado, ya que en todo el peregrinar por el desierto el espacio sagrado era de carácter móvil, la santidad, como más tarde sucederá en el Templo de Jerusalén, emanaba de la presencia divina representada por el arca de la alianza y la ley que contenía. Aun así, la mirada al interior de una sinagoga o la referencia al Templo o al santuario del desierto también fue habitual en las biblias hispanas. 
El Templo queda fuera del programa iconográfico puesto que los hechos narrados suceden antes de su construcción, es así que los útiles de culto y el mobiliario jerosolimitano se reservan para las Biblias. En estas hagadot encontramos errores e imprecisiones en el modo de reflejar las escenas de culto, que algunos achacan al desconocimiento por parte del ilustrador, argumentando así su origen cristiano, pero en lo relativo al mobiliario sagrado y la judaica representadas, marcan sin duda la tendencia de lo que habrá de ser el mueblo sagrado judío del Renacimiento, confeccionado con un cúmulo de aportes que van desde las notas bizantinas, andalusíes y castellanas a la modernidad clasicista francoitaliana. Todas ellas se hacen presentes tanto en la estructura del mueble como en el adorno, tanto en la esencia funcional como en la presencia decorativa. Como veíamos más arriba, se ha discutido mucho respecto a ambos temas: la judeidad del ilustrador y la configuración de un modelo para el mobiliario sinagogal.

El mobiliario sinagogal se reduce a unas pocas piezas de personalidad muy marcada por la función cumplida. Fundamentalmente, los que definen el espacio y la orientación de la sala de oración a Jerualén son el arón ha-qodesh o armario santo, colocado en el muro orientado al Templo de Jerusalén, y la bimá que es una tarima o torre de madera, tal y como como prefieren estas hagadot, desde la que se procede a la lectura de la Torá. Junto a ellos, deben aparecer los asientos y las estanterías o armarios para los libros y almacenaje de otros instrumentos. Los asientos pueden ser muy variados y su uso responde a una tradición precisa. Pueden ser sillas o bancos, probablemente incluso se utilizaran arquibancos que permitirían guardar los útiles para la oración, como sucede en muchas sinagogas modernas. En la Edad Media, los asientos para la mujer estaban en el espacio destinado a ellas, generalmente una tribuna elevada sobre la sala de oración de uso exclusivamente masculino. El hombre podía adquirir su banco junto al de su mujer y era habitual que a sus pies, los niños utilizasen un escabel hasta el momento de ser considerados adultos y poder ser llamados a la lectura.

Los interiores sinagogales aparecen en la Hagadá de Sarajevo (f34r, Fig. 6), en este caso una vista desde el exterior, la Hagadá Hermana (f17v), la Hagadá Kaufmann (f42r, Fig. 7) y la Hagadá de Barcelona (f65v). En esta última, hombres mujeres y niños aparecen al mismo nivel en la sala de oración ante el estuche que contiene la Torá que, envuelta en su manto, es mostrada desde la bimá. La torre para su lectura es una estructura alzada, bajo cúpula gallonada y circundada de una especie de celosía. Estos muebles además de elevados, debían ser abiertos para poder seguir con la vista al oficiante y escuchar perfectamente la lectura y comentarios. La escena de interior se decora con las lámparas de aceite en cristal de tipo islámico suspendidas del techo. La disposición de personajes y el acto se repite en la Hagadá Kaufmann, donde en primera línea una pareja asiste junto con el hijo a los pies del padre. Esta estampa ha creado gran controversia, pues en la Edad Media hispana la mujer estaba obligada a asistir, si así era su deseo, desde un espacio diferente. La bimá se representa con su escalera y las lámparas de aceite, que se han convertido prácticamente en símbolo del servicio religioso, cuelgan del techo. 


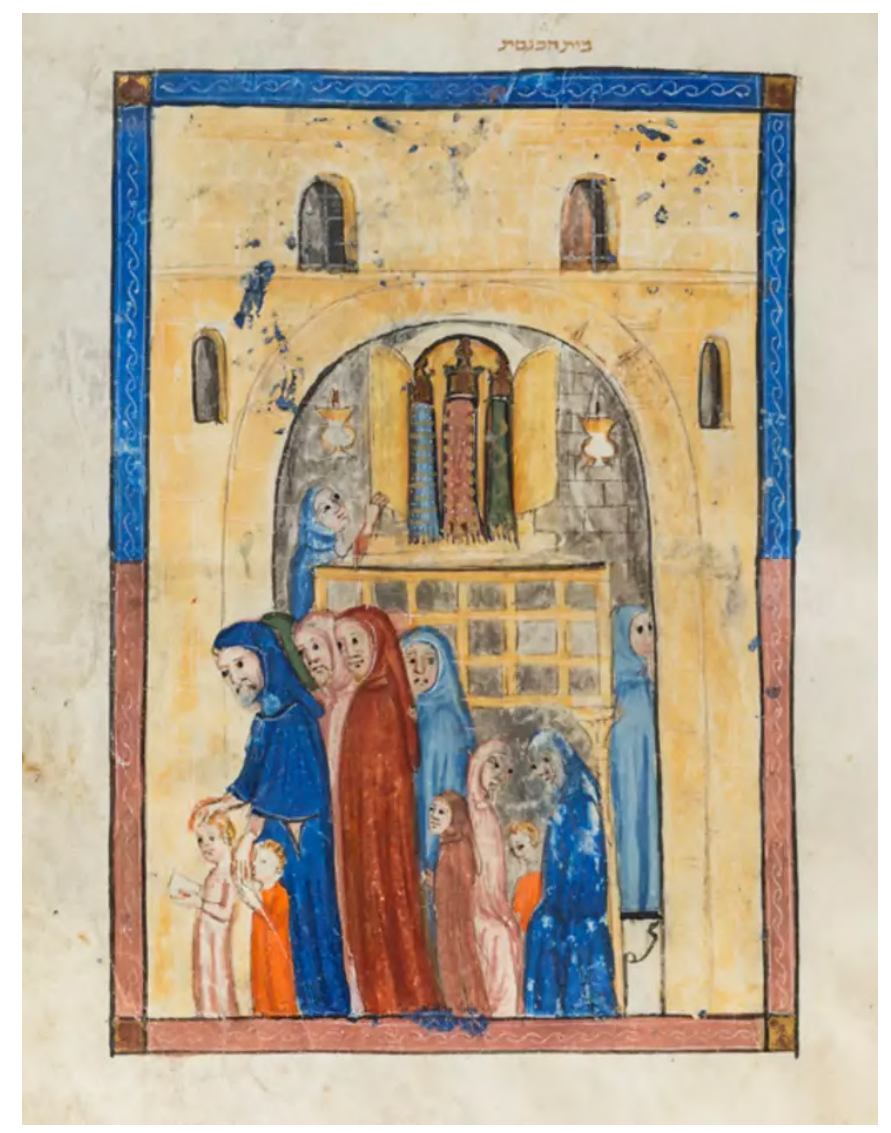

Fig. 6. Hagadá de Sarajevo, f34r.

Salida de la sinagoga.

Zemaljski Muzej Bosne i

Hercegovine, Procedente de

Cataluña, c. 1325-1350.

https://upload.wikimedia.org/

wikipedia/commons/6/62/Sarajevo_ Haggadah.png (consultado el 24/02/2021) Idan Perez, Public domain, via Wikimedia Commons

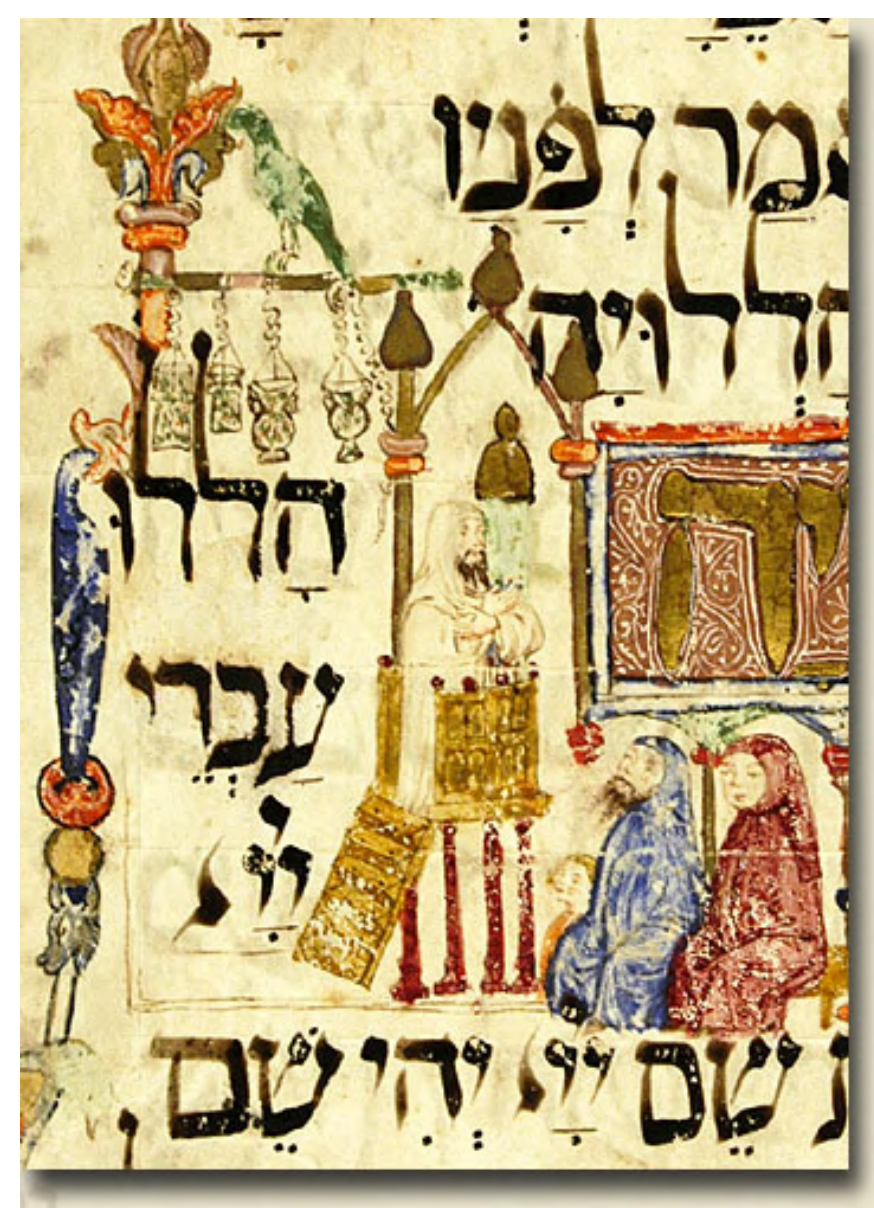

Fig. 7. Hagadá Kaufman, f42r.

Servicio en la sinagoga. Oriental Library of the Hungarian Academy of Sciences, MS A 422. Procedente de Cataluña, siglo XIV. https://upload.wikimedia. org/wikipedia/commons/9/96/ Illustration-mamluk-lamps. jpg (consultado el 24/02/2021) Unknown author, Public domain, via Wikimedia Commons 
La Hagadá Hermana incluye un mueble que no aparece en las otras, es el armario santo, representado como un edificio de sillares de piedra rememorando el Templo de Jerusalén y con las dimensiones propias de una especie de torre. Pero es curiosa la distribución simétrica de las siete lámparas dibujadas, ya que podría de alguna forma prefigurar una menorá. También aquí hombres, mujeres y niños aparecen en el mismo recinto. Los muebles sagrados representados, el arca de la ley y la bimá, muestran formas propias de la época prerrenacentista. El arca en forma de torre, que vino a sustituir en este período la nacida en época bizantina, fue habitual entre los judíos del Mediterráneo, de hecho hay una representación similar en una edición hispana de la Misné Torá de Maimónides anterior a 1351 e iluminada en el taller de Matteo di Ser Cambio (Jewish National and University Library de Jerusalén, Ms. Heb $4^{\circ} 1193$ fol. 33v $)^{50}$. La alusión a muebles en forma de torre en Sefarad no es extraña, curiosamente la recogemos en las inscripciones de dos sinagogas tipológicamente emparentadas: la de Córdoba (1315) y la de Toledo (c. 1357), pero en ambas ocasiones la expresión, que parece tomada de Ct 4, 4, se refiere no al armario santo, sino a la bimá.

El tipo de armario sagrado en forma de torreón, incluso cupulado o con techo de cuatro aguas o con gabletes góticos, debió tener su origen en Sefarad y establecerse en el norte de Italia durante el siglo XIV, desde donde influirá en el diseño del mobiliario sagrado germano. Los siglos del Barroco rescataron el tipo tradicional bizantino en forma de armario dejando atrás este tipo en forma de fortaleza, sin puertas reconocibles y disimuladas por la propia estructura del paramento externo del mueble. La filiación con la península ibérica puede establecerse a través del Libro del Esplendor o Zohar, compuesto a finales del siglo XIII o principios del siglo XIV. Los comentarios incluidos sobre los salmos, como el 118, podrían haber dado origen a la simbolización de la fe como refugio y torre inexpugnable. Podemos rastrear el recorrido de este tipo de mueble gracias a las ilustraciones de los libros italianos y alemanes estudiados por Ilia Rodov. El Renacimiento lo sustituye por un mueble en forma de fachada palaciega de dos pisos y una cubierta de tres cúpulas como muestra el arca de 1599, procedente de la sinagoga de Livorno en Vía Fernandina y a cuyo tipo debió pertenecer también la de Urbino (1500), conservada en el Jewish Museum de Nueva York. A esta se le suprimió la original cubierta tricupulada en 1624 para convertirla en un armario de ático recto ${ }^{51}$. La forma de edificio inexpugnable alude al carácter de la fe hebrea, que así debe permanecer frente al embate del entorno.

\section{A modo de conclusión}

Por encima de las variantes estilísticas o debidas al iluminador, las hagadot hispanas reflejan un deseo de reflejar la vida doméstica y litúrgica en sus imágenes. Los muebles y complementos representados son los propios del ajuar de una familia judía del momento. No hay un gusto por el detalle minucioso pero se reconoce una variada tipología caracterizada por la funcionalidad y la versatilidad. El mobiliario y objetos de judaica de estas páginas ilustradas evidencian también un gusto por el símbolo y la significación de acuerdo a la propia tradición, lo que no es óbice para una segura colaboración e intercambio con 
otros artistas hispanos o europeos, ya fuesen cristianos o musulmanes. Estas hagadot constituyen una enriquecedora muestra de la cultura sin fronteras propia del medioevo hispano, aunque en cierto modo también internacionaliza la producción artística destinada al consumo familiar de una minoría aferrada a la tradición. El medio y el motivo condicionan el tipo de escena y la tipifican. Pese a eso, la variedad de soluciones en asientos, mesas o lechos que ofrecen estos libros solo depende de la voluntad del artista. Esto puede interpretarse como una riqueza real en las piezas que sirvieron de modelo. Salvo en el mobiliario litúrgico, no podemos colegir que exista una intención ex profeso de revestir los muebles de un significado hebreo más allá de su propia utilidad y superpuesto al comúnmente admitido: un trono es un trono y lo es por oposición a una silla. Sin embargo, el moblaje sinagogal, como todos sus aderezos decorativos, si posee un significado único, preciso y trascendente que solo adquiere sentido desde la propia tradición.

\section{NOTAS}

${ }^{1}$ Carlos del Valle (ed.), La Misna (Madrid: Ed. Nacional, 1981), 1102-1103.

${ }^{2}$ Carlos del Valle (ed.), La Misna (Madrid: Ed. Nacional, 1981), 1079.

${ }^{3}$ Carlos del Valle (ed.), La Misna (Madrid: Ed. Nacional, 1981), 1094.

${ }^{4}$ Carlos del Valle (ed.), La Misna (Madrid: Ed. Nacional, 1981), 747 y 1100.

${ }^{5}$ Gabrielle Sed-Rajna, L'art juif (Paris: PUF, 1965), p. 69

${ }^{6}$ IRe 6, 31-36, II Cr 4, 9 y 22

${ }^{7}$ Bracha Yaniv, “The Origins of the ‘Two- column' Motif in European Parokhot," Jewish Art 15, (1989): 35.

${ }^{8}$ Isidore Epstein, Studies in the Communal Life of the Jews of Spain as reflected in the Responsa of Rabbi Solomon ben Adreth and Rabbi Simon ben Zemach Duran, (New York: Hermon, 1968), 60 y ss.

9 “"The Hispano-Mauresque Haggadah,” British Library, consultado 12 de enero, 2021, http://www. bl.uk/catalogues/illuminatedmanuscripts/record.asp?MSID $=19280 \&$ CollID $=96 \& N S t a r t=2737$ 10 “The Golden Haggadah,” British Library, consultado 12 de enero, 2021, http://www.bl.uk/ turning-the-pages/?id=47111807-4e9a-43de-be65-96f49c3d623c\&type=book

${ }^{11}$ Katrin Kogman-Appel, "La iluminación de libros hebreos en la Iberia bajomedieval. Hebrew Book Illumination in Late Medieval Iberia," en Biblias de Sefarad-Bibles of Sepharad, coords. F. J. del Barco y E. Alfonso, (Madrid: Ministerio de Cultura, Biblioteca Nacional, 2012), 87.

${ }^{12}$ Marianne David y Javier Muñoz-Basols, "The Sarajevo Haggadah: A Cultural Metaphor for Diaspora Studies," en Marianne. David and Javier Muñoz-Basols (eds.), Defining and ReDefining Diaspora: From Theory to Reality, (Oxford: Interdisciplinary Press, 2011), 256.

${ }^{13}$ Katrin Kogman-Appel, "La iluminación de libros hebreos en la Iberia bajomedieval. Hebrew Book Illumination in Late Medieval Iberia," en Biblias de Sefarad-Bibles of Sepharad, coords. F. J. del Barco y E. Alfonso, (Madrid: Ministerio de Cultura, Biblioteca Nacional, 2012), 107 y 110. ${ }^{14}$ Galia Pik Wajs, "El midrash y la hagadá, fuentes de la iconografía bíblica del prólogo miniado de la Hagadá de Sarajevo," De Arte 4, (2005): 18.

15 "Sarajevo Haggadah," The Bezalel Narkiss Index of Jewish Art. The Center for Jewish Art, consultado el 12 de enero, 2021, https://cja.huji.ac.il/browser.php?mode=set\&id=711

${ }^{16}$ D. H. Müller y Julius von Schlosser, Die Haggadah von Sarajevo. Eine spanische-judische handschrift des Mittelalters. Nebst einem Anhange von David Kaufman (Wien: Alfred Holder, 1898). 
${ }^{17}$ Katrin Kogman-Appel, "Jewish Art and Non-Jewish Culture: The Dynamics of Artistic Borrowing in Medieval Hebrew Manuscript Illumination," Jewish History 15, no. 3 (2001): 188. ${ }^{18}$ Katrin Kogman-Appel, "Jewish Art and Non-Jewish Culture: The Dynamics of Artistic Borrowing in Medieval Hebrew Manuscript Illumination," Jewish History 15, no. 3 (2001): 200. ${ }^{19}$ Joseph Shatzmiller, "Christian artists and Jewish patronage," en Cultural Exchange: Jews, Christians, and Art in the Medieval Marketplace, (Princeton, Oxford: Princeton University Press, 2013), 126-130.

20 "The Kaufmann Haggadah," Library of the Hungarian Academy of Sciences, Kaufmann Collection, consultado 12 de enero, 2021, http://kaufmann.mtak.hu/en/ms422/ms422-coll1.htm 21 "Ashkenazi Haggada," British Library, consultada el 7 de enero, 2021, http://www.bl.uk/ manuscripts/FullDisplay.aspx?ref=Add_MS_14762.

${ }^{22}$ Se han consultado la Hagadá Hispanomorisca (último cuarto del siglo XIII-primer cuarto del siglo XIV (c. 1300), la Hagadá Prato (c. 1300-1450), la Hagadá Graziano (c. 1300-1328), la Hagadá Dorada (c. 1320), la Hagadá Sassoon (c. 1320), la Hagadá Sister o Hermana (c. 1325-1335), la Hagadá de Sarajevo (c. 1325-1350), la Hagadá Brother o Hermano (c. 1330), la Hagadá Mocatta (c. 1330-1340), la Hagadá Rylands (c. 1330-1349), la Hagadá de Barcelona (c. 1340), la Hagadá Kaufmann (siglo XIV) y la Hagadá de Poblet (finales del siglo XIV). Pero no hemos podido acceder a la Hagadá de Modena-Bologna (c. 1325-1350), la Hagadá Cambridge (siglo XIV), la Hagadá Hamilton y la Hagadá de Parma.

${ }^{23}$ M. Ángela Franco Mata, "Relaciones artísticas entre la Haggadah de Sarajevo y la cerca exterior del coro de la catedral de Toledo," Espacio, Tiempo y Forma 6, (1993): 66.

${ }^{24}$ M. Ángela Franco Mata, "Relaciones artísticas entre la Haggadah de Sarajevo y la cerca exterior del coro de la catedral de Toledo," Espacio, Tiempo y Forma 6, (1993): 68.

${ }^{25}$ Rosa Alcoy i Pedros, "Aspectos formales en la marginalia del Maimónides de Copenhague," Espacio, Tiempo y Forma 6, (1993): 40.

26 “The Haggadah Prato," Jewish Theological Seminary, consultado 12 de enero, 2021, https:// digitalcollections.jtsa.edu/islandora/object/jts\%3A12249\#page/1/mode/1up

${ }^{27}$ Günter Böhm, Exposición de la Hagada de Sarajevo (Santiago de Chile: Biblioteca Nacional, Instituto Chileno-Yugoeslavo de Cultura, 1965), 12.

${ }^{28}$ Rachel Vishnitzer, "Illuminated Haggadahs," The Jewish Quarterly Review 13, no. 2, (1922): 202.

${ }^{29}$ María José Cano Pérez, "Contenido de la Haggadah de Barcelona," MEAH 41, no. 2, (1992): 85.

30 "Rylands Haggadah," John Rylands University Library, consultado 12 de enero, 2021, https://www.metmuseum.org/exhibitions/objects?exhibitionId=d8da48ba-e77b-4cf0-a223-79b1 280563d5\&pkgids $=189 \#$ !?perPage $=50 \&$ offset $=0$

31 "The Sister Haggadah," British Library, consultado 12 de enero, 2021, http://www.bl.uk/ catalogues/illuminatedmanuscripts/record.asp?MSID=19290\&CollID=96\&NStart=2884

32 “The Brother Haggadah,” British Library, consultado 12 de enero, 2021, http://www.bl.uk/ catalogues/illuminatedmanuscripts/record.asp?MSID=19258\&CollID=96\&NStart=1404

33 “The Haggadah Graziano," Jewish Theological Center de New York, consultado 12 de enero, 2021, https://digitalcollections.jtsa.edu/islandora/object/jts\%3A236799\#page/8/mode/1up

${ }^{34}$ Miguel Ángel Motis Dolader, "Estudio de los objetos litúrgicos de las sinagogas zaragozanas embargados por la Corona en el año 1492," Aragón en la Edad Media 6, (1984): 249.

${ }^{35}$ María José Cano Pérez, "Contenido de la Haggadah de Barcelona," MEAH 41, no. 2, (1992): 86.

${ }^{36}$ Luke Ferreter, "The power and the glory: the aesthetics of the Hebrew bible," Literature and Theology, 18, no. 2 (2004): 130.

${ }^{37}$ Katrin Kogman-Appel, "La iluminación de libros hebreos en la Iberia bajomedieval. Hebrew Book Illumination in Late Medieval Iberia," en Biblias de Sefarad-Bibles of Sepharad, coords. F. J. del Barco y E. Alfonso, (Madrid: Ministerio de Cultura, Biblioteca Nacional, 2012), 91.

${ }^{38}$ Gabrielle Sed-Rajna et al., L'art juif, (Paris : Citadelles \& Mazenod, 1995), 21. 
${ }^{39}$ M. Hundley, "Sacred Spaces, Objects, Offerings, and People in the Priestly Texts: A Reappraisal," Journal of Biblical Literature 132, no. 4 (2013): 749-767. doi:10.2307/42912465 ${ }^{40}$ Gabrielle Sed-Rajna et al., L'art juif, (Paris : Citadelles \& Mazenod, 1995), 23.

${ }^{41}$ AAVV, "Studies in Furniture Design. Fifth Study: Byzantine-Middle Age," The Decorator and Furnisher 2, no. 5 (1883): 156.

${ }^{42}$ Christine Mazzoli-Guintard y María Jesús Viguera Molins, "La casa en las miniaturas del Sulwan al-muta (Manuscrito de El Escorial número 528, s. XVI," en De puertas para adentro. La casa en los siglos XV-XVI, ed. María Elena Díez Jorge, (Granada: Comares, 2019), 343.

${ }^{43}$ Christine Mazzoli-Guintard y María Jesús Viguera Molins, "La casa en las miniaturas del Sulwan al-muta (Manuscrito de El Escorial número 528, s. XVI," en De puertas para adentro. La casa en los siglos XV-XVI, ed. María Elena Díez Jorge, (Granada: Comares, 2019), 351.

${ }^{44}$ Christine Mazzoli-Guintard y María Jesús Viguera Molins, "La casa en las miniaturas del Sulwan al-muta (Manuscrito de El Escorial número 528, s. XVI," en De puertas para adentro. La casa en los siglos XV-XVI, ed. María Elena Díez Jorge, (Granada: Comares, 2019), 351.

${ }^{45}$ También en la Hagadá Hermana este tema representa a Isaac fuera de la cama, entronizado y bajo una estructura arquitectónica gótica que sugiere un interior.

${ }^{46}$ La Hagadá Hermana reproduce el tema de manera muy similar en el f7v, cobertor púrpura sobre un voluminoso lecho blanco y abultados almohadones.

${ }^{47}$ Rodríguez Bernis, Sofia et alt., Mueble español: estrado y dormitorio, (Madrid: Museo Español de Arte Contemporáneo, Comunidad de Madrid, Consejería de Cultura, Dirección General de Patrimonio Cultural, 1990), 50.

${ }^{48}$ Rodríguez Bernis, Sofia et alt., Mueble español: estrado y dormitorio, (Madrid: Museo Español de Arte Contemporáneo, Comunidad de Madrid, Consejería de Cultura, Dirección General de Patrimonio Cultural, 1990), 31.

${ }^{49}$ Rodríguez Bernis, Sofia et alt., Mueble español: estrado y dormitorio, (Madrid: Museo Español de Arte Contemporáneo, Comunidad de Madrid, Consejería de Cultura, Dirección General de Patrimonio Cultural, 1990), 41.

${ }^{50}$ Ilia Rodov, "Tower-like torah arks, the tower of strength and the architecture of the messianic Temple," Journal of the Warburg and Courtauld Institutes 73, (2010): 67.

${ }^{51}$ Ilia Rodov, "Tower-like torah arks, the tower of strength and the architecture of the messianic Temple," Journal of the Warburg and Courtauld Institutes 73, (2010): 65-98. 